J. Environ. Sci.

Institute of Environmental Studies and Research - Ain Shams University

\title{
DETERMINATION OF SOME ESSENTIAL AND TOXIC ELEMENTS OF COMMERCIAL CHILDREN FOOD IN THE EGYPTIAN MARKETS
}

\author{
Maha A. Souror ${ }^{(1)}$; Mohammed I. Abdel Megeed ${ }^{(2)}$ \\ And Mona A. Khorshed ${ }^{(1)}$
}

1) Ministry of Agriculture and Land Reclamation, Agricultural Research Center, Central Laboratory of Residue Analysis of Pesticides and Heavy Metals in Foods (QCAP Egypt) 2) Plant Protection Department, Faculty of Agriculture, Ain Shams University

\begin{abstract}
The present work was carried out for determination of Antimony ( $\mathrm{Sb}$ ), cadmium $(\mathrm{Cd})$, chromium $(\mathrm{Cr})$, cobalt $(\mathrm{Co})$, copper $(\mathrm{Cu})$, iron $(\mathrm{Fe})$, lead $(\mathrm{Pb})$, Manganese $(\mathrm{Mn})$, nickel $(\mathrm{Ni})$, Tin $(\mathrm{Sn})$ and zinc $(\mathrm{Zn})$ in children food samples using inductively coupled plasma optical emission spectrometer (ICP-OES). The method showed that the quantification limits were varied between 0.02 and $1 \mathrm{mg} / \mathrm{kg}$. The mean recoveries \pm standard deviations at different spiking levels were varied between $81.95 \pm 3.89$ and $112.56 \pm 3.31$ $\%$ with coefficient of variation expressed as relative standard deviation ranged from 1.95 and $5.91 \%$. The method trueness was confirmed by using three different certified references materials purchased from (WEPAL) and all obtained results were with in satisfactory ranges and had acceptable recovery and Z-score values. The method precision, in terms of relative standard deviation (RSD), was being below $5.16 \%$.The method uncertainty expressed as expanded uncertainty of all validated elements was found to be $\leq 22.68 \%$. The results obtained make the method suitable for accurate determination of validated elements in different kinds of children food samples at these low concentration values. Validated method was used for the determination of metallic contaminants in 50 samples covering 19 different brands of popular biscuits, snacks, cooked potato, bake, and cake in Egypt. The result showed that, all tested samples were free from any detectable amount of $\mathrm{Pb}$. On the other hand, the resulting concentration ranges, in
\end{abstract}


$\mathrm{mg} / \mathrm{kg}$, were as follows: $<0.02-0.08(\mathrm{Cd}),<1-10.9(\mathrm{Cu}), 3.4-227.1(\mathrm{Fe})$, $1.2-7.6(\mathrm{Mn}), 1.2-3.8(\mathrm{Ni}), 1-3.5(\mathrm{Sn})$, and $3-269.1(\mathrm{Zn})$.

Keywords: Children food; ICP-OES; Essential and toxic elements; Egypt.

\section{INTRODUCTION}

Many kinds of child-consumed candy products were sold at a low price at retail stores near elementary schools. Most of the packaging is so poorly designed that the inner coating does not maintain structural integrity, allowing ink components in the outer package layer to migrate into the candy. Furthermore, candy contact surfaces of the packages have a potential for contamination because finished packaging films are frequently distributed to end users in reel form in which the outer printed surface and food contact surfaces of the packages are in contact with each other. There are many kinds of metal-based inorganic pigments. The metal components can migrate from the printed surface to the food contact surface if the package is poorly designed. In particular, heavy metals from the ink can migrate to the candy if harmful lead $(\mathrm{Pb})$ - or hexavalent chromium [Cr $(\mathrm{VI})]$ - based inks are intentionally used in the food package. Migration can be severe if the surface of the candy is sticky. For more than a century, $\mathrm{Cr}$ (VI) exposure has been known to be associated with cancer induction in humans, especially bronchial carcinoma and lung cancer (Ki-Cheol et al., 2008; Khalil et al., 2016). However, not all the $\mathrm{Cr}$ (VI) compounds are equally potent as carcinogens. In particular, the water-insoluble $\mathrm{Cr}$ (VI) compounds of particulate forms are more potent carcinogens than the water-soluble ones (Patierno et al., 1998; Holmes et al., 2005). 
Supplementation of metals in children food is currently a matter of discussion. Moreover, children food and foods may be hold toxic elements as a result of their natural presence in raw materials which be used, from contamination, or from food processing. For example, rice-based food products were recently reported to contain concentrations of arsenic above what is considered safe days (Meharg et al., 2008). Metals such as lead (Pb), cadmium $(\mathrm{Cd})$, mercury $(\mathrm{Hg})$, and arsenic (As) are considered toxic and are known to have deleterious effects, even in small quantities. Lead during pregnancy or early childhood will cause serious damage to the brain growth with the consequent loss of intellectual potential. Also, with prolonged intake of Cd may accumulate in the kidney and liver because of its long biological half-life and may lead to kidney damage (Ghuniem et al., 2019 a). Furthermore, the short term exposure to low level arsenic causes reduction in the production of leukocytes and erythrocytes, damage to blood vessels, nausea and vomiting, abnormal heartbeat, and pricking sensations in the hands and legs, its exposure for long time periods often leads to skin lesions, peripheral vascular disease, pulmonary disease and cardiovascular diseases, neurological problems, diabetes mellitus and certain types of cancers (Yoshida et al., 2004; Hopenhayn, 2006). Symptoms attributed to high level exposure to metallic mercury include lung damage, mucous membrane changes, vomiting, ausea, skin rashes, increased heart rate or blood pressure, renal dysfunction, and severe neurologic abnormalities (Asano et al., 2000; Ghuniem et al., 2019 b). 
Therefore, the aim of this study is establishing and validating an analytical method for the determination of $\mathrm{Pb}, \mathrm{Cd}, \mathrm{Sb}, \mathrm{Cu}, \mathrm{Zn}, \mathrm{Fe}, \mathrm{Cr}, \mathrm{Sn}, \mathrm{Co}$, $\mathrm{Mn}$ and $\mathrm{Ni}$ in a wide range of children food collected from Giza, Egypt.

\section{MATERIALS AND METHODS}

Apparatus: A Perkin Elmer Inductively coupled plasma optical emission spectrometer (ICP-OES) Optima 8300 coupled with ultrasonic nebulizer U5000 AT+ (CETAC). Milestone High-pressure microwave oven (Model: Ethos Up) purchased from Milestone - Italy. Water Purification System equipped with Q-POD Element coupled with Merck Millipore - Q® integral 5 (A10®) / Model : ZRXQ005T0 - USA. Mettler Toledo Top bench balance has range from $0.1 \mathrm{mg}$ to $210 \mathrm{~g}$.

Materials and Reagents: Certified reference metals stock standard solutions $(1000 \mathrm{mg} / \mathrm{L})$ of $\mathrm{Pb}, \mathrm{Cd}, \mathrm{Sb}, \mathrm{Cu}, \mathrm{Zn}, \mathrm{Fe}, \mathrm{Cr}, \mathrm{Sn}, \mathrm{Co}, \mathrm{Mn}$ and Ni prepared in 2$3 \%$ HNO3 were purchased from Merck- Germany. Concentrated Nitric acid (HNO3) $65 \%$ (w/w) was purchased from Merck - Germany. Emsure ${ }^{\circledR}$ Hydrogen peroxide (H2O2) $30 \%$ was purchased from Merck - Germany. Water was deionised in the laboratory using Water Purification System equipped with Q-POD Element coupled with Merck Millipore - Q® integral $5(\mathrm{~A} 10 \AA)$.

Sample collection: In this study, 50 children food samples corresponding to 19 different brands of biscuits, snacks, cooked potato, bake and cake were obtained randomly from local markets in Egypt. The samples consisted of 10 samples of each variety. The samples were coded and stored before analysis at conditions similar to those of retail shops. Constituents and samples types 
of the children food samples are presented in Table 1.In this study, 3 different certified reference materials (CRM) (IPE 783 Wheat powder, IPE 998 Potato powder, and IPE 200 Maize powder) were purchased from Wageningen Evaluating Programmes For Analytical Laboratories (WEPAL) Netherlands.

Sample preparation: Homogenize the sample, weigh up to $(0.5 \mathrm{~g})$ of children food samples into the microwave digestion vessel; add $0.5 \mathrm{~mL}$ of deionized water to decrease the nitrous fumes resulting from the matrix digestion. Add $8 \mathrm{~mL}$ concentrated nitric acid to the digestion vessel and shake gently then add $2 \mathrm{~mL}$ of hydrogen peroxide. Adjust the microwave oven program as $($ Power $=1800$ watt for 15 minutes until temperature reach 200 OC then let the temperature at $2000 \mathrm{C}$ for 15 minutes, finally allow the microwave venting (Power $=$ zero) until temperature $<800 \mathrm{C}$ ). After the heating cycle have been completed, allow the vessels to cool down in a water bath for about 30 min then open the vessels carefully. Rinse down the lid and the walls with deionised water inside the vessel, then transfer the residual solution in $50 \mathrm{~mL}$ volumetric flask and completed it with deionized water to the marked volume.

Instrumentation: ICP-OES is started, with the water cooler before plasma igniting. The plasma must be ignited at least 30 minutes before wavelength calibration on optima spectrometers. The measurement was carried out at optimize condition (plasma flow $=12 \mathrm{~L} / \mathrm{min}$, auxiliary flow $=0.2 \mathrm{~L} / \mathrm{min}$, nebulizer flow $=0.35 \mathrm{~L} / \mathrm{min}$, ICP radio frequency $=1400$ Watts, pump flow rate $=2.5 \mathrm{~L} / \mathrm{min}$, view distance $=15 \mathrm{~cm}$, ultrasonic nebulizer heater $=1400 \mathrm{C}$, ultrasonic nebulizer cooler $=30 \mathrm{C}$ and axial plasma view). ICP-OES was used for determination of $\mathrm{Cu}, \mathrm{Zn}, \mathrm{Fe}, \mathrm{Sn}, \mathrm{Mn}, \mathrm{Cr}, \mathrm{Co}, \mathrm{Cd}, \mathrm{Pb}, \mathrm{Sb}$, and $\mathrm{Ni}$ in 
children food samples at different basic wavelengths which give higher sensitivity, lower relative standard deviation, sharpness peaks and no spectral interferences. The basic wavelengths were 205.56, 257.61, 238.204, 327.393, 202.548, 230.786, 227.02, 214.440, 220.353, 206.836 and $189.927 \mathrm{~nm}$ for $\mathrm{Cr}$, $\mathrm{Mn}, \mathrm{Fe}, \mathrm{Cu}, \mathrm{Zn}, \mathrm{Co}, \mathrm{Ni}, \mathrm{Cd}, \mathrm{Pb}, \mathrm{Sb}$, and $\mathrm{Sn}$, respectively.

Analytical quality assurance: Analytical method validation of ICP-OES for analysis of $\mathrm{Pb}, \mathrm{Cd}, \mathrm{Sb}, \mathrm{Cu}, \mathrm{Zn}, \mathrm{Fe}, \mathrm{Cr}, \mathrm{Sn}, \mathrm{Co}, \mathrm{Mn}$ and $\mathrm{Ni}$ in children food was assessed by determining several analytical parameters such as: limit of quantification (LOQ), method linearity, accuracy, and measurement uncertainty according to Eurachem (2014) and Eurachem / CITAC guidelines (2012). 
J. Environ. Sci.

Institute of Environmental Studies and Research - Ain Shams University

\section{Table(1): Constituents of children food samples}

\begin{tabular}{|c|c|c|}
\hline $\begin{array}{l}\text { Item } \\
\text { Name }\end{array}$ & Code & Constituents \\
\hline \multirow{10}{*}{ Biscuits } & A1 & $\begin{array}{c}\text { Wheat flour, sugar, Vegetable oil, fructose syrup, Sodium bicarbonate, and } \\
\text { sodium acid }\end{array}$ \\
\hline & $\mathrm{A} 2$ & corn flour, milk, oil, and Glucose starch \\
\hline & A3 & $\begin{array}{c}\text { Wheat flour, Sugar, Palm oil, fructose, salt, citric acid, ammonium\& sodium, } \\
\text { and bicarbonate de sodiumE503-E500 }\end{array}$ \\
\hline & A4 & $\begin{array}{c}\text { Wheat flour, Sugar, Palm oil, fructose, salt, citric acid, ammonium\& sodium, } \\
\text { and bicarbonate de sodiumE503-E500 }\end{array}$ \\
\hline & A5 & wheat flour, sugar, Vegetable oil, Sodium bicarbonate, and sodium acid e500 \\
\hline & A6 & $\begin{array}{c}\text { wheat flour, veg oil, cocoa powder, salt, sugar, e500 why milk, palm oil, and } \\
\text { vegetable oil }\end{array}$ \\
\hline & A7 & $\begin{array}{l}\text { Wheat flour, sugar, refined, vegetable oils, skimmed milk powder, cocoa butter } \\
\text { substitute, leavening agents, sodium bicarbonate and e500 vanilla }\end{array}$ \\
\hline & A8 & $\begin{array}{c}\text { Wheat flour, date, sugar, Vegetable oil, palm, Glucose syrup, corn starch, } \\
\text { sorbitol, bicarbonates and ammonium }\end{array}$ \\
\hline & A9 & $\begin{array}{c}\text { Sugar, Vegetable oil, palm oil, wheat flour, cocoa powder, skimmed } \\
\text { milk, whey milk, e450 vanilla }\end{array}$ \\
\hline & A10 & $\begin{array}{l}\text { Wheat flour, Sugar, hydrogenated vegetable oil, cocoa powder, soya lecithin } \\
\text { E322, potassium sorbateE211, salt, food flavour }\end{array}$ \\
\hline \multirow{10}{*}{$\begin{array}{c}\text { Cooked } \\
\text { potato }\end{array}$} & B1 & Selected fresh potatoes, sun flower oil, salt, and sweet chilli seasoning \\
\hline & $\mathrm{B} 2$ & Selected fresh potatoes, sun flower oil, salt, and cheddar Shallats seasoning \\
\hline & B3 & Selected fresh potatoes, sun flower oil, and sea salt \\
\hline & B4 & $\begin{array}{c}\text { Fresh potatoes, vegetable oil, chicken flavour, wheat derivative, and milk } \\
\text { derivative }\end{array}$ \\
\hline & B5 & Fresh potatoes, refined palm olien oil, vinegar, and salt flavour \\
\hline & B6 & Fresh potatoes, refined palm olien oil, and spiced cheese flavour \\
\hline & B7 & Fresh potatoes, refined palm olien oil, tomato flavour \\
\hline & B8 & Fresh potatoes, refined palm olien oil, chilli lemon flavour \\
\hline & B9 & Fresh potatoes, vegetables oil, salt and vinegar, wheat and gluten \\
\hline & B10 & Fresh potatoes, vegetables oil, chilli lemon flavour, gluten \\
\hline \multirow{10}{*}{ Snacks } & $\mathrm{C} 1$ & Corn, Vegetable oil, cheese flavour, gluten, lactose, and wheat \\
\hline & $\mathrm{C} 2$ & Corn, Vegetable oil, chilli flavour, gluten, lactose, and wheat \\
\hline & $\mathrm{C} 3$ & Corn, Vegetable oil, cheese flavour, gluten, lactose, and wheat \\
\hline & $\mathrm{C} 4$ & Corn gratis, Vegetable oil, chilli flavour, lactose, wheat, and gluten \\
\hline & $\mathrm{C} 5$ & $\begin{array}{c}\text { Corn grits, Vegetable oil, Ketchup and hot dog flavour, Milk, Lactose, and } \\
\text { wheat gluten }\end{array}$ \\
\hline & C6 & Corn, Vegetable oil, Corn flour, cheese flavour salt, and milk \\
\hline & $\mathrm{C} 7$ & Corn, Vegetable oil, Corn flour, cheese flavour salt, and milk \\
\hline & $\mathrm{C} 8$ & Vegetable oil, corn flour, salt, and peanut flavour \\
\hline & C9 & Vegetable oil, corn flour, salt, and cheese flavour \\
\hline & $\mathrm{C} 10$ & Vegetable oil, corn flour, salt, and cheese flavour \\
\hline
\end{tabular}


Cont. Table(1): Constituents of children food samples

\begin{tabular}{|c|c|c|}
\hline $\begin{array}{c}\text { Item } \\
\text { Name }\end{array}$ & Code & Constituents \\
\hline \multirow{10}{*}{ Bake } & D1 & $\begin{array}{c}\text { Wheat flour, Water, palm olien, Cheese flavour, salt, sugar, yeast, and } \\
\text { natural e } 160 \mathrm{~b}\end{array}$ \\
\hline & D2 & Wheat flour, Cheese flavour, Salt, water, and palm olien \\
\hline & D3 & Wheat flour, water, olien oil, yeast, and butter flavour \\
\hline & D4 & Wheat flour, water, olien oil, yeast, and cheese flavour \\
\hline & D5 & Wheat flour, water, olien oil, yeast, and salt flavour \\
\hline & D6 & Wheat flour, water, olien oil, yeast, and salt and vinegar flavour \\
\hline & D7 & Wheat flour, water, olien oil, yeast, and sweet chilli flavour \\
\hline & D8 & Wheat flour, water, olien oil, yeast, and pizza flavour \\
\hline & D9 & Wheat flour, ketchup flavour, Salt, water, palm olien, and yeast \\
\hline & D10 & Wheat flour, ketchup flavour, Salt, water, palm olien, and yeast \\
\hline \multirow{10}{*}{ Cake } & E1 & $\begin{array}{c}\begin{array}{c}\text { Sugar, Wheat flour, hydrogenated Vegetable oil, egg, Coca, water and milk } \\
\text { powder }\end{array} \\
\end{array}$ \\
\hline & E2 & $\begin{array}{l}\text { wheat flour, sugar, whole, egg, milk powder, vegetable oil, cocoa, and } \\
\text { water }\end{array}$ \\
\hline & E3 & $\begin{array}{c}\text { Sugar, Wheat flour, hydrogenated Vegetable oil, egg, Coca, water and milk } \\
\text { powder }\end{array}$ \\
\hline & E4 & $\begin{array}{c}\text { Wheat flour, water, egg, vegtables oil, fructose, dextrose powder, whey } \\
\text { powder and salt }\end{array}$ \\
\hline & E5 & $\begin{array}{c}\text { Sugar, eggs, palm olien, hydrogenated, water, wheat flour, cocoa powder } \\
\text { and wheat starch }\end{array}$ \\
\hline & E6 & $\begin{array}{c}\begin{array}{c}\text { Sugar, eggs, palm olien, hydrogenated, water, wheat flour, milk powder and } \\
\text { wheat starch }\end{array} \\
\end{array}$ \\
\hline & E7 & Wheat Flour, Sugar, palm oil, Cocoa, Salt, glucose, and bicarbonate \\
\hline & E8 & $\begin{array}{c}\text { Sugar, Vegetable oil, palm oil, wheat flour, egg, dextrose, cocoa and } \\
\text { fructose syrup }\end{array}$ \\
\hline & E9 & $\begin{array}{c}\text { Wheat flour, sugar, water, egg, cocoa, fructose, salt, Vegetable oil, and } \\
\text { vanilla }\end{array}$ \\
\hline & E10 & $\begin{array}{l}\text { Wheat flour, sugar, water, egg, cocoa, fructose, salt Vegetable oil, full cream } \\
\text { and soya protein }\end{array}$ \\
\hline
\end{tabular}

\section{RESULTS AND DISCUSSION}

Method Validation: Validation was performed to ensure the reliability of the method. Before being used for quantitative analysis of $\mathrm{Pb}, \mathrm{Cd}, \mathrm{Sb}, \mathrm{Cu}, \mathrm{Zn}, \mathrm{Fe}$, $\mathrm{Cr}, \mathrm{Sn}, \mathrm{Co}, \mathrm{Mn}$ and $\mathrm{Ni}$ in children food samples, the method was validated by determining some analytical parameters. 
J. Environ. Sci.

Institute of Environmental Studies and Research - Ain Shams University

1) Practical limit of quantification (LOQ): The practical limits of quantification, expressed as the lowest validated spike level with acceptable criteria for trueness and precision. The minimum practical concentrations of tested elements in the analysed samples, which can be determined with acceptable accuracy were performed by analyse eight replicates at $(1 \mathrm{mg} / \mathrm{kg})$ for $\mathrm{Mn}, \mathrm{Cr}, \mathrm{Co}, \mathrm{Ni} \mathrm{Fe}, \mathrm{Cu}, \mathrm{Sn}$ and $\mathrm{Zn}$, at $(0.4$ $\mathrm{mg} / \mathrm{kg})$ for $\mathrm{Sb}$, at $(0.05 \mathrm{mg} / \mathrm{kg})$ for $\mathrm{Pb}$, and at $(0.02 \mathrm{mg} / \mathrm{kg})$ for $\mathrm{Cd}$. At these LOQs values the coefficients of variation expressed as relative standards deviations (RSD \%) were found to be 4.75, 3.37, 4.10, 3.74, 4.00, 5.91, 4.58, 4.19, 3.91, 3.63, and $5.44 \%$ for $\mathrm{Cr}$, Co , Mn, Ni, Zn, Sn, $\mathrm{Cu}, \mathrm{Fe}, \mathrm{Cd}, \mathrm{Pb}$, and $\mathrm{Sb}$, respectively.

2) Recovery test: The recovery tests were performed using 8 replicates of spiking soft drinks samples at 4 different concentrations levels. The spiking levels used for recovery test were at 1, 2, 5, and $10 \mathrm{mg} / \mathrm{kg}$ for $\mathrm{Mn}$, $\mathrm{Cr}$, Co, $\mathrm{Ni} \mathrm{Fe}, \mathrm{Cu}, \mathrm{Sn}$ and $\mathrm{Zn}$, at $0.4,0.8,1$ and $2 \mathrm{mg} / \mathrm{kg}$ for $\mathrm{Sb}$, at 0.05 , $0.1,0.5$, and $1 \mathrm{mg} / \mathrm{kg}$ for $\mathrm{Pb}$, and at $0.02,0.1,0.5$, and $1 \mathrm{mg} / \mathrm{kg}$ for $\mathrm{Cd}$. The mean recoveries \pm standard deviations at different levels varied between $81.95 \pm 3.89$ and $112.56 \pm 3.31 \%$ with coefficient of variation expressed as relative standard deviation ranged from 1.95 and $5.91 \%$.

3) Linearity: The values of correlation coefficients must be greater than 0.995 for accurate quantification as analytical response is linear over certain concentration ranges (Eurachem, 1998; Jeevanaraj et al., 2015).

(a) Linearity of the calibration curves: The dynamic linear range found to be linear from 0.05 up to $6 \mathrm{mg} / \mathrm{L}$ for $\mathrm{Mn}, \mathrm{Cr}, \mathrm{Co}, \mathrm{Ni} \mathrm{Fe}, \mathrm{Cu}, \mathrm{Sn}$ and $\mathrm{Zn}$ and 
from 1 up to $100 \mu \mathrm{g} / \mathrm{L}$ for $\mathrm{Pb}, \mathrm{Cd}$, and $\mathrm{Sb}$. All calibration curves correlation coefficients values were greater than 0.995 see Table 2 .

(b) Linearity of the method: The linearity of the method was checked using 4 different spiking levels of soft drinks samples at $1,2,5$, and $10 \mathrm{mg} / \mathrm{kg}$ for $\mathrm{Mn}, \mathrm{Cr}, \mathrm{Co}, \mathrm{Ni} \mathrm{Fe}, \mathrm{Cu}, \mathrm{Sn}$ and $\mathrm{Zn}$, at $0.4,0.8,1$ and $2 \mathrm{mg} / \mathrm{kg}$ for $\mathrm{Sb}$, at $0.05,0.1,0.5$, and $1 \mathrm{mg} / \mathrm{kg}$ for $\mathrm{Pb}$, and at $0.02,0.1,0.5$, and $1 \mathrm{mg} / \mathrm{kg}$ for $\mathrm{Cd}$. The method linearity was found to be linear from LOQs values up to $10 \mathrm{mg} / \mathrm{kg}$ for $\mathrm{Mn}, \mathrm{Cr}, \mathrm{Co}, \mathrm{Ni} \mathrm{Fe}, \mathrm{Cu}, \mathrm{Sn}$ and $\mathrm{Zn}$, from LOQs values up to1 $\mathrm{mg} / \mathrm{kg}$ for $\mathrm{Pb}$ and $\mathrm{Cd}$, and from LOQs values up to $2 \mathrm{mg} / \mathrm{kg}$ for $\mathrm{Sb}$. All the linearity of the method correlation coefficients values were greater than 0.995 see Table 2.

Table(2): Results of correlation coefficients of calibration curves and the linearity of the method.

\begin{tabular}{|c|c|c|c|c|}
\hline \multirow[b]{2}{*}{$\begin{array}{c}\text { Elemen } \\
\mathbf{t}\end{array}$} & \multicolumn{2}{|c|}{ Dynamic linear range } & \multicolumn{2}{|c|}{ Method linearity } \\
\hline & $\begin{array}{l}\text { Correlation } \\
\text { coefficients } \\
\end{array}$ & Slope & $\begin{array}{l}\text { Correlation } \\
\text { coefficients } \\
\end{array}$ & Slope \\
\hline $\mathrm{Cr}$ & 0.99924 & 0.1232 & 0.9996 & 1.0621 \\
\hline $\mathrm{Co}$ & 099954 & 0.1876 & 0.9999 & 1.0383 \\
\hline $\mathrm{Mn}$ & 0.99988 & 0.4624 & 0.9998 & 0.9509 \\
\hline $\mathrm{Ni}$ & 099963 & 0.0570 & 0.9999 & 0.9584 \\
\hline $\mathrm{Zn}$ & 0.99940 & 0.2437 & 0.9995 & 0.8581 \\
\hline $\mathrm{Sn}$ & 0.99966 & 0.04295 & 1.0000 & 1.0079 \\
\hline $\mathrm{Cu}$ & 0.99957 & 0.1078 & 0.9982 & 0.8663 \\
\hline $\mathrm{Fe}$ & 0.99988 & 0.5749 & 0.9984 & 0.8693 \\
\hline $\mathrm{Cd}$ & 0.99982 & 0.5289 & 0.9986 & 0.8905 \\
\hline $\mathrm{Pb}$ & 0.99989 & 0.07932 & 0.9993 & 0.9851 \\
\hline $\mathrm{Sb}$ & 0.99990 & 0.1964 & 0.9998 & 0.9814 \\
\hline
\end{tabular}

4. Method Accuracy: In this study, method accuracy was studied as two parameters trueness and precision (repeatability and reproducibility). 
J. Environ. Sci.

Institute of Environmental Studies and Research - Ain Shams University

(a) Trueness: In this study, the trueness of the validated method was confirmed by using three certified reference materials (CRM) from WEPAL (IPE 783 Wheat powder, IPE 998 Potato powder, and IPE 200 Maize powder). Z-scores were calculated using the following equation:

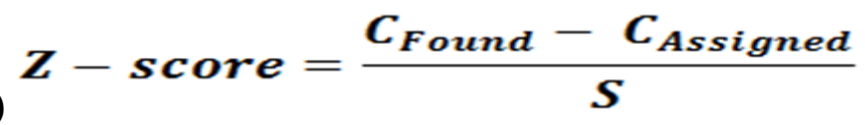

Z-score: a statistical measure that quantifies the distance a data point is from the mean

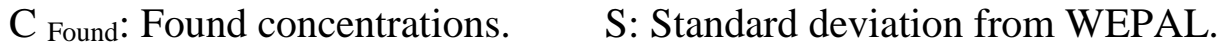

$\mathrm{C}_{\text {assigned: }}$ Assigned values from WEPAL.

All measured results were within satisfactory range and had acceptable Z-score $(-2 \leq$ Z-score $\leq 2)$ see Table 3 .

Table(3): Results of different certified reference materials from WEPAL.

\begin{tabular}{|c|c|c|c|c|c|c|c|c|}
\hline CRM Type & Elements & $\begin{array}{c}\text { Found } \\
\text { Concentration } \\
\mathrm{s} \\
\end{array}$ & $\begin{array}{l}\text { Assigned } \\
\text { values }\end{array}$ & \multicolumn{3}{|c|}{$\begin{array}{c}\text { Satisfactory } \\
\text { Ranges }\end{array}$} & $\begin{array}{c}\text { Uni } \\
\text { ts }\end{array}$ & $\begin{array}{c}\text { Z- } \\
\text { scor } \\
\text { e }\end{array}$ \\
\hline \multirow{4}{*}{$\begin{array}{l}\text { IPE } 783 \\
\text { Wheat } \\
\text { powder }\end{array}$} & Copper & 3.48 & 3.31 & 2.38 & 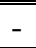 & 4.24 & $\mathrm{mg} /$ & 0.37 \\
\hline & Iron & 32.90 & 34.50 & 22.9 & - & 46.0 & $\mathrm{mg} /$ & -0.28 \\
\hline & Manganese & 17.94 & 19.00 & 15.2 & - & 22.8 & $\mathrm{mg} /$ & -0.56 \\
\hline & Zinc & 24.11 & 23.00 & 18.4 & - & 27.6 & $\mathrm{mg} /$ & 0.48 \\
\hline \multirow{4}{*}{$\begin{array}{l}\text { IPE } 998 \\
\text { Potato } \\
\text { powder }\end{array}$} & Copper & 6.55 & 7.00 & 5.20 & - & 8.80 & $\mathrm{mg} /$ & -0.50 \\
\hline & Iron & 41.70 & 42.30 & 24.9 & - & 59.6 & $\mathrm{mg} /$ & -0.07 \\
\hline & Manganese & 5.51 & 5.42 & 3.49 & - & 7.35 & $\mathrm{mg} /$ & 0.09 \\
\hline & Zinc & 19.02 & 19.30 & 14.9 & - & 23.6 & $\mathrm{mg} /$ & -0.13 \\
\hline \multirow{6}{*}{$\begin{array}{l}\text { IPE } 200 \\
\text { Maize } \\
\text { powder }\end{array}$} & Cadmium & 39.65 & 38.80 & 28.0 & - & 49.5 & $\mu \mathrm{g} /$ & 0.16 \\
\hline & Copper & 2.74 & 2.59 & 1.74 & - & 3.44 & $\mathrm{mg} /$ & 0.35 \\
\hline & Iron & 88.87 & 86.00 & 66.4 & - & 105. & $\mathrm{mg} /$ & 0.29 \\
\hline & Lead & 315.12 & 290.00 & 175. & - & 405. & $\mu \mathrm{g} /$ & 0.44 \\
\hline & Manganese & 16.48 & 15.20 & 12.3 & - & 18.0 & $\mathrm{mg} /$ & 0.90 \\
\hline & Zinc & 14.95 & 15.90 & 13.4 & - & 18.3 & $\mathrm{mg} /$ & -0.78 \\
\hline
\end{tabular}


(b) Precision: In this study, method of precision was confirmed by studding two component repeatability and reproducibility.

(I) Repeatability: The repeatability test was performed by analysing 8 replicates of fortified soft drink sample by the same operator and short intervals of time. The results of repeatability test expressed as relative standard deviation were found to be $3.99,2.33,2.67,2.21,3.03,2.74,2.26$, 2.23, 3.96, 2.50, and $2.08 \%$ for $\mathrm{Cr}, \mathrm{Co}, \mathrm{Mn}, \mathrm{Ni}, \mathrm{Zn}, \mathrm{Sn}, \mathrm{Cu}, \mathrm{Fe}, \mathrm{Cd}, \mathrm{Pb}$, and $\mathrm{Sb}$, respectively.

(II) Reproducibility: In this study intra-laboratory reproducibility test was performed by analysing 30 replicates of fortified soft drinks samples (at 10 $\mathrm{mg} / \mathrm{kg}$ for $\mathrm{Cr}, \mathrm{Co}, \mathrm{Mn}, \mathrm{Ni}, \mathrm{Zn}, \mathrm{Sn}, \mathrm{Cu}$, and Fe, at $2 \mathrm{mg} / \mathrm{kg}$ for $\mathrm{Sb}$, and at 1 $\mathrm{mg} / \mathrm{kg}$ for $\mathrm{Cd}$ and $\mathrm{Pb}$ by different analysts on several days. The results of reproducibility test expressed as relative standard deviation were found to be $4.32,3.21,3.26,3.25,3.43,2.73,2.99,3.47,4.85,4.94$, and $5.16 \%$ for $\mathrm{Cr}, \mathrm{Co}, \mathrm{Mn}, \mathrm{Ni}, \mathrm{Zn}, \mathrm{Sn}, \mathrm{Cu}, \mathrm{Fe}, \mathrm{Cd}, \mathrm{Pb}$, and $\mathrm{Sb}$, respectively.

5. Measurement Uncertainty: Accumulated data from different quality control procedures was used for estimation of measurement uncertainty. Parameter associated with the result of a measurement that characterises the dispersion of the values that could reasonably be attributed to the measured. The parameter may be, for example, a standard deviation or the width of a confidence interval. For estimating the overall uncertainty, it may be necessary to take each source of uncertainty and treat it separately to obtain the contribution of each source. Each of the separate contributions to uncertainty is referred to as an uncertainty component. When it expressed as relative standard deviation an uncertainty component 
is known as relative standard uncertainty. The uncertainty component due to precision was investigated from intra-laboratory precision. The uncertainty component due to bias of the analytical procedure was investigated from recovery data using spiked samples, a significance test (t-test) was applied to test whether the recovery was significantly different from $100 \%$ or not. The uncertainty component due to sample processing, which represent homogeneity of analyte in analytical sample according to codex guidelines was taken as a default value (10\%) (Codex Alimentarius Commission, 2003).The uncertainty due to reference standard preparation was estimated by accounting for reference standard purity, volumetric flask and pipettes using normal and triangle distributions. Normal distribution was used in case of calculation uncertainty due to reference stock standards purity, while triangle distribution was used in case of calculation uncertainty due to volumetric flask and pipettes. The uncertainty component due to reference standards preparations was found to be equal to $0.82 \%$. The total uncertainty combined standard uncertainty, equal to the positive square root of the sum of the squares of the individual uncertainty components as shown in the flowing equation (2):

$$
U_{\text {Combined }}=\sqrt{\left(U_{\text {precision }}\right)^{2}+\left(U_{\text {Bias }}\right)^{2}+\left(U_{\text {Reference }}\right)^{2}+\left(U_{\text {sample Processing }}\right)^{2}}
$$

Expanded uncertainty must be used for quantitative analysis in analytical chemistry. Expanded uncertainty was obtained by multiplying the combined uncertainty, by a coverage factor $k$, at confidence level of $95 \%(k=2)$. The 
measurement uncertainties expressed as expanded uncertainties were found to be $22.06 \%, 21.14 \%, 21.18 \%, 21.18 \%, 21.54 \%, 20.83 \%, 21.41 \%, 21.61$ $\%, 22.56 \%, 22.36 \%$, and $22.68 \%$ for Cr, Co, Mn, Ni, Zn, Sn, Cu, Fe, Cd, $\mathrm{Pb}$, and $\mathrm{Sb}$, respectively see Table 4 .

Table(4): Results of uncertainty components.

\begin{tabular}{|c|c|c|c|c|c|c|}
\hline \multirow{2}{*}{ Element } & \multicolumn{6}{|c|}{ Uncertainty Components } \\
\cline { 2 - 7 } & $\begin{array}{c}\text { Standard } \\
\text { Preparation }\end{array}$ & Bias & $\begin{array}{c}\text { Sample } \\
\text { Processing }\end{array}$ & Precision & $\begin{array}{c}\text { Combined } \\
\text { Uncertainty }\end{array}$ & $\begin{array}{c}\text { Expanded } \\
\text { Uncertainty }\end{array}$ \\
\hline \hline $\mathrm{Cr}$ & $82.00 \%$ & $1.51 \%$ & $10 \%$ & $4.32 \%$ & $11.03 \%$ & $22.06 \%$ \\
\hline $\mathrm{Co}$ & $82.00 \%$ & $0.89 \%$ & $10 \%$ & $3.21 \%$ & $10.57 \%$ & $21.14 \%$ \\
\hline $\mathrm{Mn}$ & $82.00 \%$ & $0.89 \%$ & $10 \%$ & $3.26 \%$ & $10.59 \%$ & $21.18 \%$ \\
\hline $\mathrm{Ni}$ & $82.00 \%$ & $0.93 \%$ & $10 \%$ & $3.25 \%$ & $10.59 \%$ & $21.18 \%$ \\
\hline $\mathrm{Zn}$ & $82.00 \%$ & $1.89 \%$ & $10 \%$ & $3.43 \%$ & $10.77 \%$ & $21.54 \%$ \\
\hline $\mathrm{Sn}$ & $82.00 \%$ & $0.60 \%$ & $10 \%$ & $2.73 \%$ & $10.42 \%$ & $20.83 \%$ \\
\hline $\mathrm{Cu}$ & $82.00 \%$ & $2.24 \%$ & $10 \%$ & $2.99 \%$ & $10.71 \%$ & $21.41 \%$ \\
\hline $\mathrm{Fe}$ & $82.00 \%$ & $1.99 \%$ & $10 \%$ & $3.47 \%$ & $10.80 \%$ & $21.61 \%$ \\
\hline $\mathrm{Cd}$ & $82.00 \%$ & $1.76 \%$ & $10 \%$ & $4.85 \%$ & $11.28 \%$ & $22.56 \%$ \\
\hline $\mathrm{Pb}$ & $82.00 \%$ & $1.22 \%$ & $10 \%$ & $4.78 \%$ & $11.18 \%$ & $22.36 \%$ \\
\hline $\mathrm{Sb}$ & $82.00 \%$ & $1.13 \%$ & $10 \%$ & $5.16 \%$ & $11.34 \%$ & $22.68 \%$ \\
\hline
\end{tabular}

\section{Quality control}

(a) Reagent blank: The reagent blank sample should be analysed with each set of sample. Reagent blank sample contain $8 \mathrm{~mL}$ of concentrated $\mathrm{HNO}_{3}$ $(65 \%)+2 \mathrm{~mL} \mathrm{H}_{2} \mathrm{O}_{2}(30 \%)$.

(b) Control samples: The performance of method is continuously tested using recovery test. Each analysed batch of soft drinks samples must contain control sample. Sample is spiked with suitable amount of standard solution to get $10 \mathrm{mg} / \mathrm{kg}$ for $\mathrm{Cr}, \mathrm{Co}, \mathrm{Mn}, \mathrm{Ni}, \mathrm{Zn}, \mathrm{Sn}, \mathrm{Cu}$, and $\mathrm{Fe}$, to get 2 $\mathrm{mg} / \mathrm{kg}$ for $\mathrm{Sb}$, and to get $1 \mathrm{mg} / \mathrm{kg}$ for $\mathrm{Cd}$ and $\mathrm{Pb}$.

(c) Control charts: Control chart was used to monitor the stability of analytical precision. The results of control samples are recorded on the control chart. In case of individual point falls outside the stated limits 100 
J. Environ. Sci.

Institute of Environmental Studies and Research - Ain Shams University

(upper control limit (UCL), upper warning limit (UWL), mean central line , lower control limit (LCL) and lower warning limit (LWL)), the source or sources of error must be identified and corrected (Funk et al., 1995).

Analyses of children food samples: Fifty children food having different brands were analysed by the validated method, and the results are presented in Table 5. Various concentrations of tested elements were detected in all samples. The results showed that the highest concentration of $\mathrm{Cd}, \mathrm{Cu}, \mathrm{Zn}, \mathrm{Fe}$, Mn, Sn, and Ni was determined in the sample numbers D9, D1, C7, D1, D1, $\mathrm{C} 7$, and $\mathrm{C} 7$, respectively.

Table(5): Elements compositions of the children food samples in ( $\mathrm{mg} / \mathrm{kg})$.

\begin{tabular}{|c|c|c|c|c|c|c|c|c|c|c|c||}
\hline Sample & Cr & Co & Cu & Fe & Mn & Ni & Zn & Sn & Cd & Pb & Sb \\
\hline \hline A1 & ND & ND & 2.5 & 14.6 & 4.4 & $<1$ & 5.9 & $<1$ & ND & ND & $<0.4$ \\
\hline A2 & ND & ND & 1.1 & 91.6 & 2.4 & ND & 4.3 & $<1$ & ND & ND & $<0.4$ \\
\hline A3 & ND & ND & ND & 6.5 & 3.2 & ND & 3.5 & $<1$ & ND & ND & ND \\
\hline A4 & ND & ND & $<1$ & 8.6 & 3.4 & $<1$ & 4.3 & $<1$ & ND & ND & $<0.4$ \\
\hline A5 & $<1$ & ND & 3.2 & 58.4 & 3.6 & ND & 33.5 & $<1$ & ND & ND & $<0.4$ \\
\hline A6 & $<1$ & ND & 2.4 & 12.3 & 5.4 & $<1$ & 8.9 & $<1$ & ND & ND & $<0.4$ \\
\hline A7 & $<1$ & $<1$ & 5.9 & 49.8 & 6.7 & $<1$ & 14.7 & $<1$ & $<0.02$ & ND & $<0.4$ \\
\hline A8 & ND & ND & $<1$ & 7.1 & 2.3 & ND & 3 & $<1$ & ND & ND & ND \\
\hline A9 & ND & $<1$ & 4.7 & 45.1 & 4.9 & 1.4 & 11 & $<1$ & $<0.02$ & ND & $<0.4$ \\
\hline A10 & ND & ND & 3.9 & 17.1 & 3.6 & $<1$ & 8.7 & $<1$ & ND & ND & ND \\
\hline B1 & $<1$ & ND & 4.9 & 10.4 & 4 & ND & 6.9 & ND & $<0.02$ & ND & $<0.4$ \\
\hline B2 & ND & $<1$ & 5.5 & 8.5 & 3.2 & $<1$ & 9.5 & $<1$ & $<0.02$ & ND & $<0.4$ \\
\hline B3 & ND & ND & 4.8 & 9 & 3.4 & ND & 9.3 & $<1$ & 0.02 & ND & $<0.4$ \\
\hline B4 & $<1$ & ND & 6.4 & 6 & 3.7 & $<1$ & 6 & $<1$ & 0.04 & ND & $<0.4$ \\
\hline Sample & Cr & Co & Cu & Fe & Mn & Ni & Zn & Sn & Cd & Pb & Sb \\
\hline B5 & ND & $<1$ & 7.9 & 23.5 & 4 & $<1$ & 11 & $<1$ & $<0.02$ & ND & $<0.4$ \\
\hline B6 & ND & $<1$ & 8.3 & 11.2 & 3.7 & $<1$ & 9.7 & $<1$ & $<0.02$ & ND & $<0.4$ \\
\hline B7 & ND & $<1$ & 6.7 & 10.8 & 3.4 & $<1$ & 9 & $<1$ & ND & ND & $<0.4$ \\
\hline B8 & ND & ND & 4.6 & 14.8 & 4.2 & ND & 9 & $<1$ & ND & ND & $<0.4$ \\
\hline B9 & ND & $<1$ & 3.6 & 8.5 & 3.01 & ND & 4.6 & $<1$ & $<0.02$ & ND & $<0.4$ \\
\hline B10 & $<1$ & ND & 3 & 10.9 & 2.6 & $<1$ & 6.4 & ND & $<0.02$ & ND & $<0.4$ \\
\hline C1 & $<1$ & ND & ND & 17.9 & 1.2 & 1.6 & 33.4 & $<1$ & ND & ND & ND \\
\hline C2 & ND & ND & 1.7 & 22.2 & 1.9 & $<1$ & 31.9 & 1.2 & ND & ND & $<0.4$ \\
\hline C3 & ND & ND & ND & 20.74 & 1.7 & $<1$ & 39.7 & 1 & ND & ND & $<0.4$ \\
\hline C4 & ND & ND & 4.6 & 16.7 & 2.3 & ND & 58.2 & 1.8 & ND & ND & $<0.4$ \\
\hline
\end{tabular}


Cont. Table(5): Elements compositions of the children food samples in $(\mathrm{mg} / \mathrm{kg})$.

\begin{tabular}{|c|c|c|c|c|c|c|c|c|c|c|c|}
\hline Sample & $\mathrm{Cr}$ & Co & $\mathbf{C u}$ & $\mathbf{F e}$ & Mn & $\mathrm{Ni}$ & Zn & Sn & Cd & $\mathbf{P b}$ & Sb \\
\hline C5 & ND & ND & ND & 13.2 & 1.2 & $<<1$ & $\begin{array}{l}55.9 \\
\end{array}$ & $<<1$ & ND & ND & ND \\
\hline C6 & ND & ND & ND & 24.7 & 1.2 & 2.5 & 50.3 & $<1$ & ND & ND & ND \\
\hline $\mathrm{C} 7$ & ND & ND & 9.9 & 26.1 & 2.1 & 3.8 & 269.1 & 3.5 & ND & ND & $<0.4$ \\
\hline $\mathrm{C} 8$ & $<1$ & ND & $<1$ & 3.4 & 3.2 & $<1$ & 76.7 & 1.1 & ND & ND & $<0.4$ \\
\hline C9 & $<1$ & ND & $<1$ & 16.5 & 1.8 & $<1$ & 67 & $<1$ & ND & ND & $<0.4$ \\
\hline $\mathrm{C} 10$ & ND & ND & ND & 20 & 1.8 & $<1$ & 53.5 & $<1$ & ND & ND & $<0.4$ \\
\hline D1 & $<1$ & ND & 10.9 & 227.1 & 7.6 & ND & 12.1 & 2 & $<0.02$ & ND & $<0.4$ \\
\hline D2 & ND & ND & $<1$ & 20.3 & 2.6 & ND & 5.1 & $<1$ & $<0.02$ & ND & ND \\
\hline D3 & ND & ND & 10.6 & 52.3 & 6.2 & $<1$ & 12.7 & 2 & $<0.02$ & ND & $<0.4$ \\
\hline D4 & ND & ND & 2.5 & 16.3 & 3.9 & $<1$ & 6.1 & $<1$ & ND & ND & ND \\
\hline D5 & ND & ND & 1.7 & 32.3 & 4.5 & $<1$ & 6.6 & $<1$ & ND & ND & ND \\
\hline D6 & ND & ND & ND & 36.7 & 4.1 & $<1$ & 5.8 & $<1$ & ND & ND & ND \\
\hline D7 & ND & ND & 1.3 & 55.4 & 5 & ND & 6.7 & $<1$ & $<0.02$ & ND & $<0.4$ \\
\hline D8 & ND & ND & $<1$ & 40.9 & 4.3 & ND & 7.2 & $<1$ & 0.05 & ND & $<0.4$ \\
\hline D9 & ND & ND & $<1$ & 31.1 & 5.7 & $<1$ & 10.7 & $<1$ & 0.08 & ND & $<0.4$ \\
\hline D10 & ND & ND & ND & 25.5 & 2.7 & $<1$ & 5.8 & $<1$ & ND & ND & ND \\
\hline E1 & ND & ND & 1.6 & 12 & 2.2 & $<1$ & 7 & $<1$ & ND & ND & ND \\
\hline E2 & ND & ND & 2.3 & 15 & 2.6 & $<1$ & 6.6 & $<1$ & ND & ND & $<0.4$ \\
\hline E3 & ND & ND & 2.2 & 48.9 & 4 & 1.2 & 7.2 & $<1$ & ND & ND & $<0.4$ \\
\hline E4 & $<1$ & ND & 2.4 & 36.2 & 3.1 & $<1$ & 7.9 & $<1$ & ND & ND & ND \\
\hline E5 & ND & $<1$ & 5 & 52.4 & 6.1 & $<1$ & 14.7 & $<1$ & ND & ND & $<0.4$ \\
\hline E6 & ND & ND & 3.3 & 7.8 & 2.5 & $<1$ & 6.3 & $<1$ & $<0.02$ & ND & $<0.4$ \\
\hline E7 & ND & ND & ND & 17.5 & 1.6 & $<1$ & 31 & $<1$ & ND & ND & $<0.4$ \\
\hline E8 & ND & ND & 1.9 & 5 & 2.4 & ND & 8.9 & $<1$ & ND & ND & $<0.4$ \\
\hline E9 & $<1$ & ND & 3.9 & 15.9 & 3.1 & ND & 10.1 & $<1$ & ND & ND & $<0.4$ \\
\hline E10 & $<1$ & ND & 6 & 23.1 & 1.3 & ND & 4.4 & 1.3 & ND & ND & $<0.4$ \\
\hline $\begin{array}{c}\text { Maximum } \\
\text { Limits }(\mathrm{mg} / \mathrm{kg})\end{array}$ & - & - & - & - & - & - & - & 50 & 0.04 & 0.05 & - \\
\hline
\end{tabular}

Antimony is a cumulative toxic element with obscure biological function and its physicochemical and toxic properties depend on its binding form and oxidation state. Antimony trioxide ( $\mathrm{Sb} 2 \mathrm{O} 3)$ is used as a catalyst in the manufacture of polyethylene terephthalate (PET) worldwide. Sb2O3 is a suspected carcinogen and is listed as a priority pollutant by EU and the USEPA (Ross and Adrian, 2009; Ghuniem et al., 2019 c). In this study, 74\% of the total numbers of analysed samples have detectable amount of 
antimony, but all these concentrations levels were less than quantification limit in various brands of children food samples.

Cadmium is the seventh most toxic heavy metal as per Agency for Toxic Substances and Disease Registry (ATSDR) ranking. Cadmium is also present as an impurity in several products including fertilizers, pesticides, detergents and refined petroleum products. Some possible food sources of cadmium are in peanuts, soybeans, rice, medicinal herbs, lettuce, corn, oats, wheat, spinach, fish, shrimps and mushroom. Exposure to cadmium at very high levels can result in serious health problems related to bone defects in humans and animals liver and kidneys and can cause death (Monisha et al., 2014; Raja and Namburu, 2014). The concentration of cadmium in this study was ranged between $(<0.02$ and $0.08 \mathrm{mg} / \mathrm{kg})$ in the various brands of children food . The highest concentration of cadmium was found in bakes samples. On the other hand, all snacks samples were free from any detectable amount of Cd.

Chromium is used in a number of industrial applications, including industrial water cooling, electroplating, tanning, paper pulp production, and petroleum refining. The $\mathrm{Cr}$ (III) is biologically essential for its role in protein and sugar metabolism, while $\mathrm{Cr}$ (VI) is potentially toxic and carcinogenic, and has adverse impact on metabolic processes (Mandina and Tawanda, 2013; Swapnil et al., 2017). In this study, $26 \%$ of the total numbers of analysed samples have detectable amount of chromium, but all these concentrations levels were less than quantification limit in various brands of children food samples. 
Cobalt and its compounds are widely distributed in nature and are part of numerous anthropogenic activities. Cobalt is an essential metal that is found in the active site of B12 vitamin and represents an important role in biochemical reactions of life. Cobalt sources were allocated to four exposure settings: dietary, environmental, occupational, and medical exposure. Oral intake of cobalt supplements and internal exposure are the main source of the highest systemic cobalt concentrations inside human body. Excessive exposure has been shown to induce various adverse health effects. Toxicological effects of cobalt include vasodilation, flushing and cardiomyopathy in animals and human (Claudia et al., 2017; Laura et al., 2017). In this study, $16 \%$ of the total numbers of analysed samples have detectable amount of cobalt, but all these concentrations levels were less than quantification limit in various brands of children food samples.

Copper is one of the essential heavy metals found in all animals and food chain and environment, including soil and water and it is an essential nutrient for humans and animals in small amounts. The biological functions of copper include red blood cell synthesis, normal iron metabolism, cell metabolism; connective tissue metabolism and bone development. Acute poisoning from intake of excessive copper can cause vomiting, temporary gastrointestinal distress with symptoms such as nausea and abdominal pain. Exposure to high doses of copper can cause liver toxicity that resulted in death (Sevcikova et al., 2011; Manju, 2015; Izah et al., 2016). The concentration of copper in this study was ranged between $(<1$ and $10.9 \mathrm{mg} / \mathrm{kg}$ ) in the various brands of children food. The highest concentration of copper was found in bake samples. $30 \%$ of bake samples have copper contents below the quantification 
limit, while $20 \%$ of biscuit and snacks samples have copper contents below the quantification limit. On the other hand, all analysed cooked potato samples have copper concentrations levels above the quantification limit with mean concentrations $(5.57 \mathrm{mg} / \mathrm{kg})$, while $90 \%$ of analysed cake samples have copper concentrations levels above the quantification limit with mean concentrations $(2.86 \mathrm{mg} / \mathrm{kg})$.

Iron is the fourth most abundant element which constitutes the most of the part of earth crust. Iron is essential for almost every organism due to its involvement in a wide variety of metabolic processes. The most common disease resulting from iron deficiency is anaemia in human. While excess intake of iron can cause several health implications such as an increased risk for heart diseases, cancer and endocrine problems, arthritis, diabetes and liver disease (Ramesh et al., 2016; Chitra et al., 2017). The concentration of iron in this study was ranged between $(3.4$ and $227.1 \mathrm{mg} / \mathrm{kg}$ ) in the various brands of children food. The highest concentration of iron was found in snacks samples, while, the lowest concentration of iron was found in bake samples. The mean concentrations of iron in biscuit, cooked potato, snacks, bake, and cake were found to be $31.11,11.36,18.14,53.79$, and $23.38 \mathrm{mg} / \mathrm{kg}$, respectively.

Lead is a highly toxic metal whose widespread use has caused extensive environmental contamination and health problems in many parts of the world. Lead breaks the blood-brain barrier and interferes with the normal development of brain in infants (Andre et al., 2005; Raja and Namburu, 2014). In this study, all analysed samples of the various brands of infant formulae were free from any detectable amount of lead $(\mathrm{Pb})$. 
Manganese is the twelfth most abundant element in the earth crust and is naturally present in food, water, soil and. rocks. Manganese is an essential nutrient present in several food items for humans, plants and animals and is required for development, growth and maintenance of health. Ingestion of manganese from drinking water may pose significant risks for children's health, especially neurodevelopment (Santamaria, 2008; Valfredo et al., 2009; Maryse et al., 2018). The concentration of manganese in this study was ranged between $(1.2$ and $7.6 \mathrm{mg} / \mathrm{kg})$ in the various brands of children food . The highest concentration of manganese was found bake samples, while the lowest concentration of manganese was found snacks samples. The mean concentrations of iron in biscuit, cooked potato, snacks, bake, and cake were found to be $3.99,3.52,1.84,4.66$, and $2.89 \mathrm{mg} / \mathrm{kg}$, respectively.

Nickel is an essential micronutrient for microorganisms, plants and certain mammals which present in a wide range of primary crops, animals and foodstuffs. Nickel is used in many industrial applications such as the manufacturing of stainless steel. Occupational exposure has been shown to give rise to elevated levels of nickel in urine, blood and body tissues (Aleksandra and Urszula, 2008; Francesco et al., 2009; Pizzutelli, 2011). In this study, $58 \%$ of the total numbers of analysed samples have detectable amount of nickel less than quantification limit in various brands of children food samples, while $10 \%$ of analysed samples have nickel concentrations levels above the quantification limit with mean concentrations $(2.1 \mathrm{mg} / \mathrm{kg})$.

Tin is one of the toxic metals, which could be accumulating in the human body and animals tissues. Tin may be released into the atmosphere from windstorms, volcanic emission, forest fires, roads, and farming activities. 
Exposure to a large amount of tin in canned food is taken daily over a long period, acute effects such as stomach aches, anaemia, occur problems in liver and kidney (Cima, 2011; Hamid and Homeira, 2013). In this study, $80 \%$ of the total numbers of analysed samples have detectable amount of tin less than quantification limit in various brands of children food samples, while $16 \%$ of analysed samples have tin concentrations levels above the quantification limit with mean concentrations $(1.74 \mathrm{mg} / \mathrm{kg})$.

Zinc is one of the essential elements for living cells for many organisms and zinc deficiency has been associated with multiple adverse conditions, including impaired immune function. Excess amount of zinc can pose serious toxicity to human health as well as to the ecosystem, therefore, zinc is consider as both an essential and potentially toxic metal. Zinc is widely distributed in different food such as meats, fish, poultry, cereals and dairy foods. Oral zinc supplementation can reduce the effects of the common cold; however, there is strong clinical evidence that intranasal zinc gluconate gel treatment for this purpose causes anosmia or the loss of the sense of smell among people who had used intranasal zinc sprays and gels (Heidi et al., 2016; Man., 2017). The concentration of zinc in this study was ranged between ( 3 and $269.1 \mathrm{mg} / \mathrm{kg}$ ) in the various brands of children food. The highest concentration of zinc was found in biscuit samples, while, the lowest concentration of iron was found in snacks samples. The mean concentrations of zinc in biscuit, cooked potato, snacks, bake, and cake were found to be $9.78,8.14,73.57,7.88$, and $10.41 \mathrm{mg} / \mathrm{kg}$, respectively. 


\section{CONCLUSION}

In this study, ICP OES technique was used to validate the analytical method for the determination of trace and toxic element $\mathrm{s}$ in children food. The validated methodology proved to be fast, easy and simple, and so it can be very useful for routine laboratories. The method quantifications limits were found to be much lower than the maximum permissible limits of metal contaminants stated by Egyptian, WHO and European standards in food. This method can be suitable and applied for all kinds of children food. This method can be recommended for the Egyptian standard organisation for the determination of $\mathrm{Pb}, \mathrm{Cd}, \mathrm{Sb}, \mathrm{Cu}, \mathrm{Zn}, \mathrm{Fe}, \mathrm{Cr}, \mathrm{Sn}, \mathrm{Co}, \mathrm{Mn}$ and $\mathrm{Ni}$ i in children food as well as help with the elucidation of toxicological studies, which may be interesting for health. A study of the levels of 11 trace and toxic metals was conducted using a total of 50 samples of children food collected from supermarkets Giza, Egypt. The analysis of the data indicated that all samples were free from any detectable amount of $\mathrm{Pb}$ while, different concentrations levels of $\mathrm{Cd}, \mathrm{Cu}, \mathrm{Zn}, \mathrm{Fe}, \mathrm{Sn}, \mathrm{Mn}$ and $\mathrm{Ni}$ were quantified in the analysed children food sample. The data from this study will be useful to health authorities as well as researchers interested in epidemiological studies.

\section{RECOMMENDATIONS}

Microwave digestion method was especially recommended for fast, easy and simple, and so it can be very useful for routine laboratories for determination of lead $(\mathrm{Pb})$, cadmium $(\mathrm{Cd})$, antimony $(\mathrm{Sb})$, copper $(\mathrm{Cu})$, iron $(\mathrm{Fe})$, zinc $(\mathrm{Zn})$, chromium $(\mathrm{Cr})$, manganese $(\mathrm{Mn})$, tin $(\mathrm{Sn})$, cobalt $(\mathrm{Co})$ and nickel (Ni) in children food samples. Also hyphenation between ultrasonic 
nebuliser with inductively coupled plasma optical emission spectrometer can make the method suitable for accurate determination of elements in different kinds of children food samples even at low concentration values.

\section{ACKNOWLEDGMENT}

The authors gratefully acknowledge the use of the facilities, equipment, and resources of the Central Laboratory of Residue Analysis of Pesticides and Heavy Metals in Food during the period of the development of this paper. The authors also would like to thank Prof. Dr. Ashraf Mahmoud El marsafy lab director.

\section{REFERENCES}

Aleksandra, D. C. and Urszula, B. (2008): The impact of nickel on human health. J. Elementol., (13), 685-696.

Andre, L. O. S.; Paulo, R. G. B.; Silvana do Couto, J. and Josino, C. M. (2005): Dietary intake and health effects of selected toxic elements. Braz. J. Plant Physiol., (17) 79-93.

Asano, S.; Eto, K.; Kurisaki, E.; Gunji, H.; Hiraiwa, K.; Sato, M.; Sato, H.; Hasuike, M.; Hagiwara, N. and Wakasa, H. (2000): Acute inorganic mercury vapour inhalation poisoning. Pathol. Int., (50), $169-174$.

Chitra, V.; Kavita, T. and Anupam, B. S. (2017): Determination of iron (III) in food, biological and environmental samples. Food Chem., (221), 1415-1420.

Cima, F. (2011): Tin: environmental pollution and health effects. Environ Pollut., Health Eff. 351-359.

Claudia, H. W.; Adnivia, S. C. M.; Erik, S. J. G.; Vivian, S. L.; Carolina de Castro, B.; Nirmal, T. K.; Renata, F. and Andre, H.R. (2017): Toxicity assessment of arsenic and cobalt in the presence of aquatic humic substances of different molecular sizes. Ecotoxicol. Environ. Saf., (139), 1-8. 
Codex Alimentarius Commission. (2003): Joint FAO/WHO Food Standards Programme, 26th Session, (FAO, Rome, Italy, 2003).

Eurachem Guide. (1998): The Fitness for Purpose of Analytical Methods. A Laboratory Guide to Method Validation and Related Topics, First Edition.

Eurachem Guide. (2014): The Fitness for Purpose of Analytical Methods, A Laboratory Guide to Method Validation and Related Topics, Second Edition.

Eurachem/CITAC Guide CG 4. (2012): Quantifying Uncertainty in Analytical Measurement, Third Edition.

Francesco, P.; Beatrice, B.; Giovanni, F.; Stefano, C. and Antonio, C. (2009): Role of diet in nickel dermatitis. Chem. Biomed. Methods J. (2), $55-57$.

Funk, W.; Dammann V. and Donnevert, G. (1995): Quality Assurance in Analytical Chemistry, (VCH Publisher, New York, USA).

Ghuniem, M. M.; Khroshed, M. A. and Souaya, E. R. (2019 a): Method validation for direct determination of some trace and toxic elements in soft drinks by inductively coupled plasma mass spectrometry. Int. J. Environ. Anal. Chem., (99), 516-540.

Ghuniem, M. M.; Khroshed, M. A. and Souaya, E. R. (2019 b): Optimization and Validation of an Analytical Method for the Determination of Some Trace and Toxic Elements in Canned Fruit Juices Using Quadrupole Inductively Coupled Plasma Mass Spectrometer. J. AOAC Int. (102), 262-270.

Ghuniem, M. M.; Khroshed, M. A. and Souaya, E. R. (2019 c): Determination of some essential and toxic elements composition of commercial infant formula in the Egyptian market and their contribution to dietary intake of infants. Int. J. Environ. Anal. Chem., doi: 10.1080/03067319.2019.1637426

Hamid, A. and Homeira, E. (2013): Imprinted polymer-based extraction for speciation analysis of inorganic tin in food and water samples, React. Funct. Polym., (73), 634-640.

Heidi, H.; Kavitha, S. V.; George, S. D. J.; Divaker, Howard, G .S. and Mary, B. G. (2016): Mechanistic studies of the toxicity of zinc gluconate in the olfactory neuronal cell line Odora. Toxicol. in Vitro, (35) 24-30. 
Holmes, A. L.; Wise, S. S.; Xie, H.; Gordon, N.; Thompson, W. D. and Wise, J. P. S. (2005): Lead ions do not cause human lung cell to escape chromate-induced cytotoxicity. Toxicol. Appl. Pharm., (203), $167-176$.

Hopenhayn, C. (2006): Arsenic in Drinking Water: Impact on Human Health. Elements, (2), 103- 107.

Izah, S. C.; Chakrabarty, N. and Srivastav, A. L. (2016): A review on heavy metal concentration in potable water sources in Nigeria: Human health effects and mitigating measures. Exp. Health., (8), 285304.

Jeevanaraj, P.; Hashim, Z.; Elias S. M. and Aris, A.Z. (2015): Total mercury $(\mathrm{THg})$, lead $(\mathrm{Pb})$, cadmium $(\mathrm{Cd})$ and arsenic (As) in hair samples: method validation and quantification among women at reproductive age in Selangor. Int. J. Sci. Basic Appl. Res., (24), $332-347$.

Khalil, M. M. H.; Khorshed, M. A.; Ghuniem, M. M. (2016): Development of Analytical method for Determination of some essential and toxic elements in some canned and Homemade baby food samples in Giza, Res J. Chem. Environ. Sci., (4), 15-23.

Ki-Cheol, K.; Yong-Bae, P.; Myung-Jin, L.; Jung-Beom, K.; Jeong-Weon, H.; Dae-Hwan, K.; Jung-Bok, L.; and Jong-Chan, K. (2008): Levels of heavy metals in candy packages and candies likely to be consumed by small children. Food Res. Int., (41), 411-418.

Laura, L.; Bart, V.; Catherine, V. D. S.; Floris, W. and Leen, M. (2017): Cobalt toxicity in humans. A review of the potential sources and systemic health effects. Toxicol., (387), 43-56.

Man, J. K.; Maxim, I. B.; Jung-Seok, Y.; Seunghak, L.; Yun, H. H.; Ju, Y. L.; Bhoopesh, M. and Kenneth, M. K. (2017): Transformation of zinc-concentrate in surface and subsurface environments: Implications for assessing zinc mobility/toxicity and choosing an optimal remediation strategy. Environ. Pollut. (226) 346-355.

Mandina, S. and Tawanda, M. (2013): Chromium, an essential nutrient and pollutant: A review. Afr. J. Pure Appl. Chem., (7), 310-317.

Manju, M. (2015): Effects of heavy metals on human health, Int. J. Res., 1-7.

Maryse, F. B.; Céline, S.; Pierre, C. and Delphine, F. (2018): Low level exposure to manganese from drinking water and cognition in school-age children. Neurotoxicol., (64), 110-117. 
Meharg, A.A. G.; Sun, P.N.; Williams, E.; Adomako, C.; Deacon, Y. G.; and Zhu. (2008): Inorganic arsenic levels in baby rice are of concern, Environ. Pollut., (152), 746-749.

Monisha, J.; Tenzin, T.; Naresh, A., Blessy, B. M. and Krishnamurthy, N. B. (2014): Toxicity, mechanism and health effects of some heavy metals. Interdiscip. Toxicol., (7), 60-72.

Patierno, S. R.; Banh, D. and Landolph, J. R. (1988): Transformation of $\mathrm{C} 3 \mathrm{H} / 10 \mathrm{~T} 1 / 2$ mouse embryo cells by insoluble lead chromate but not soluble calcium chromate: relationship to mutagenesis and internalization of lead chromate particles. Cancer Res., (47) 2342-2346.

Pizzutelli, S. (2011): Systemic nickel hypersensitivity and diet: myth or reality?. Eur. Ann. Allergy. Clin. Immunol., (43), 5-18.

Raja, R. T. and Namburu, S. (2014): Impact of heavy metals on environmental pollution. J. Chem. Pharm., Sci., (3), 175-181.

Ramesh, K. S.; Shivraj, H .N. and Young-Soo, K. (2016): Food science and technology for management of iron deficiency in humans: A review. Trends Food Sci. Technol., (53), 13-22.

Ross G. C. and Adrian P. H. (2009): The exposure to and health effects of antimony. Indian J. Occupat. Environ. Med., (13), 3-10.

Santamaria, A. B. (2008): Manganese exposure, essentiality \& toxicity. Indian J. Med. Res. (128), 484-500.

Sevcikova, M.; Modra, H.; Slaninova, A. and Svobodova, Z. (2011): Metals as a cause of oxidative stress in fish: A review. Vet. Med., (56) 537-546.

Swapnil, T.; Manas, K. D. and Bhupendra, K.S. (2017): Cloud point extraction and diffuse reflectance-Fourier transform infrared spectroscopic determination of chromium (VI): a probe to adulteration in food stuffs. Food Chem., (221) 47-53.

Valfredo, A. L.; Cleber, G. N. and Marcos, A.B. (2009): An automated preconcentration system for the determination of manganese in food samples. J. Food Compos. Anal., (22) 337-342.

Yoshida, T.; Yamauchi H. and Fan-Sun, G. (2004): Chronic health effects in people exposed to arsenic via the drinking water: dose-response relationships in reviewToxicol. Appl. Pharmacol., (198), 243252. 


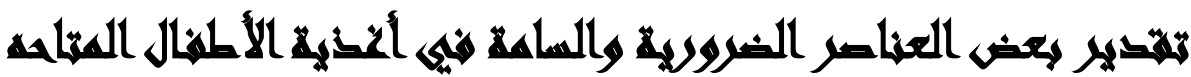 هيكه الأسورة المصرية}

[०]

مها أحمد سرور (')- محمد إبراهيم عبد المجيد()- منى عبد العزيز خورشيد(1) (Y) المعمل المركزى لتحليل متنقيات المبيدات والعناصر النقيلة في الأغذية، مركز البحوث الزبراعية

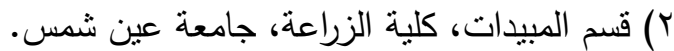

\section{المستخلص}

في هذه الدراسة، نم التحقق من صحة طريقة تحليل سريعة وسهلة وبسيطة لتحديد العناصر

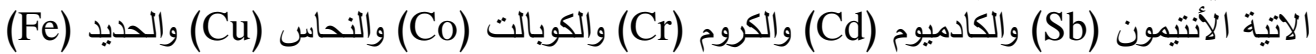

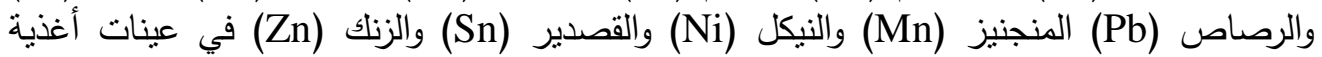

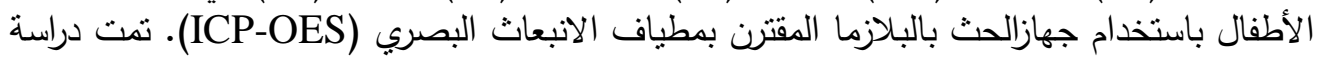

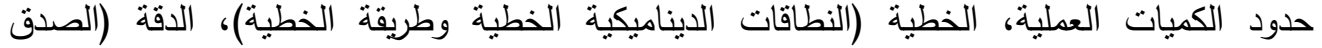
والكفأه)، ومعاملات عدم اليقين في القياس. أظهرت الطريقة أن حدود القياس الكمي كانت تتراوح بين

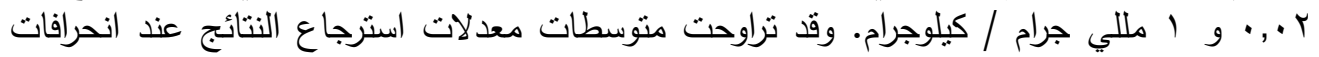

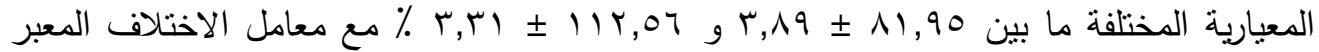
عنه بالانحرافات المعيارية النسبية التي تزاوحت ما بين

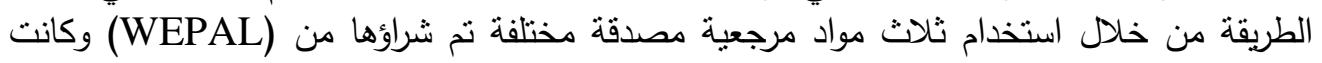

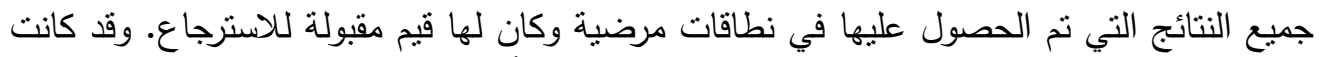

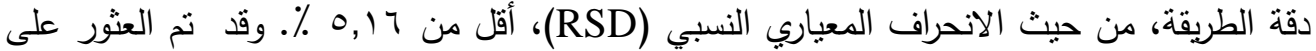

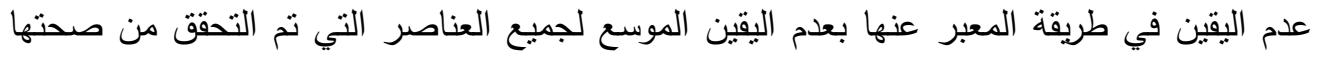

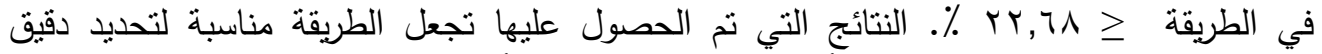

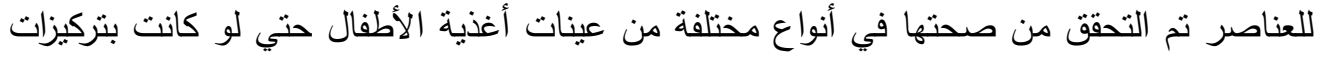

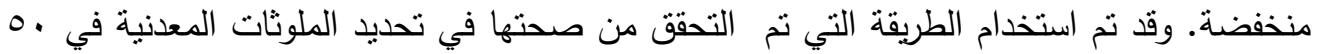

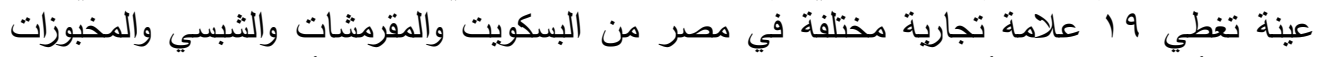
والكيك. أظهرت النتيجة أن جميع العينات التي تم اختبة أنبارها كانت خالية من أبي كمية يمكن اكتشافها

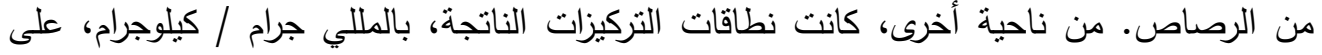

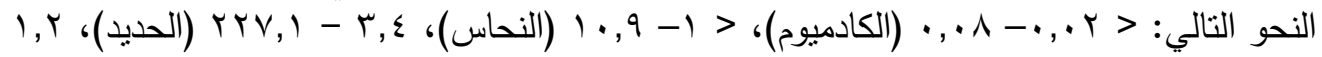

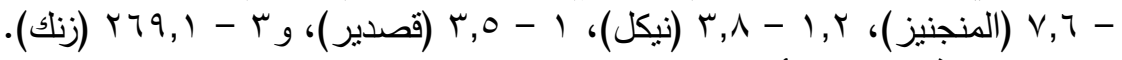

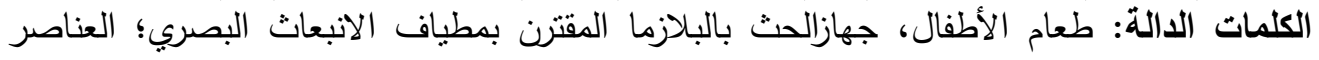

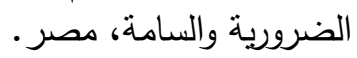

